\title{
The Use of Auricular Biometrics to Identify Age and Sex in Egyptian Population Sample
}

\author{
Hanan F. EL-Faresy' ${ }^{1}$ Fatma M. Elgazzar, Mona S. Elgohary and Mona M. Heshmat ${ }^{2}$ \\ ${ }^{1}$ Medicolegal Institute, El Mansoura Department, Ministry of Justice, Egypt \\ ${ }^{2}$ Department of Forensic Medicine and Clinical Toxicology, Tanta University, Tanta, Egypt
}

\begin{abstract}
Determination of age and sex represents a challenging task to the forensic anthropologist and this explored the field of biometrics. Recognition using ear biometrics is promising and has received broad attention. In spite of this, no previous studies addressed this topic to identify Egyptian population traits. Hence, the aim of this study was to investigate the possible role of some auricular dimensions in identifying age and sex of Egyptian population sample. This study was undertaken on 426 selected healthy male and female Egyptians, aged 4-82 years. For each subject, both right and left auricular length, width, and position were measured by electronic digital caliper. The enrolled subjects were divided into six non-overlapping age groups. Statistical significant differences were found in the mean length, width, and position of both right and left auricles among the different studied age groups and between both sexes. Additionally, regression analysis revealed the following equation (for age estimation; Age (years) $=-91.884+(19.921 \mathrm{x}$ right auricular length). Moreover, all the studied measurements were significantly valid (area under the ROC curve greater than 0.6) in discriminating males from females but, the Lt auricular width showed the best accuracy (72.4\%). Finally, it could be concluded that auricular length, width, and position could be useful tools for age and sex estimation of Egyptian population.
\end{abstract}

Keywords Auricle; biometrics; age estimation; sex determination; Egyptian population

\section{Introduction}

$\mathrm{T}$ he challenges of age and sex identification, investigated by forensic anthropologists, have explored the field of biometrics, which is efficient and convenient in identity authentication (Masaoud et al., 2013). As one of the most promising biometric-based methods, ear recognition has received broad attention and research (Chen et al., 2015). Ear biometrics can be applied as a recognition tool when one individual must be identified and in postmortem forensic procedures for identification (Singh and Singh, 2014).

The ear structure is rich and full of features which are stable, changes little with facial expressions and unaffected by factors such as health and clothing. In addition, the appearance of the auricle is also relatively unaffected by aging, making it better suited for long-term identification (Kumar and Wu, 2012; Purkait, 2015).

Three procedures are applied for ear biometrics namely; manual anthropometry by using caliper, twodimensional photogrammetry and three-dimensional computer-aided digitizers. Manual anthropometry of ear is a readily available, easy and accurate method to collect data for verifying the identity based on external ear measurements. On the other hand, it is time consuming (Chen and Bhanu, 2007; Kumar and Wu, 2012).

Reference wise, there are limited data on external ear biometrics and its role in identification in Egyptian population. Hence, the aim of the present study was to use some external ear dimensions as characteristic traits in identifying age and sex in a sample of Egyptian population sample.

\section{Subjects and methods}

\section{Subjects}

A cross-sectional study was undertaken on 426 healthy male and female Egyptians, aged 4-82 years. Depending on the pattern of ear growth, the enrolled subjects were divided into six non-overlapping age groups as follow: from 4 years to less than 5 years, from 5 years to less than 7 years, from 7 years to less than 18 years, from 18 
years to less than 40 years, from 40 years to less than 60 years and more than 60 years.

The study participants were informed about all the details of the procedures, and gave written consent. For those under age of 21 years, an informed consent was obtained from their parents/legal guardians. Confidentiality was maintained by making code number for every subject.

The study was carried out after getting the approval from the research ethics committee of Tanta Faculty of Medicine. Detailed history and clinical examination were done to exclude subjects with a previous history of craniofacial trauma, ear diseases, congenital anomalies, disfigurements or surgeries.

\section{Methods}

For every subject, both right (Rt) and left (Lt) ears were studied. During data collection the head should be held erect (in the resting position) with the eyes facing forward. In addition, the facial profile should be vertical and the patient viewed from the side. The parameters of each ear were collected by inspection and palpation then measured by electronic digital caliper (Fig 1) according to Gripp et al. (2013). These included:

\section{Ear Length}

Maximum distance between the superior aspect of the outer rim of the helix to the most inferior border of the ear lobe of the auricle (Fig 2).

Pitfalls: In the presence of a posteriorly rotated ear, the measurement should still be taken from the most superior portion of the helix to the inferior portion of the auricle, even though the axis of this measurement is not in the vertical plane. If the superior aspect of the helix is over folded, do not unfold it to measure the length (Gripp et al., 2013).

\section{Ear Width}

Width of the auricle measured transversely from the anterior base of the tragus, which can be palpated, through the region of the external auditory canal to the margin of the helical rim, at the widest point (Fig 3).

Pitfalls: It should be careful to take this measurement in the transverse dimension; otherwise, a falsely elevated value will be obtained. With cupped or protuberant ears, the most accurate measurement is obtained with the auricle pressed firmly against the head (Gripp et al., 2013).

\section{Ear Position}

It means the location of the superior attachment of the auricle .Noting that the size and rotation of the external ear are not relevant. It can be detected by drawing an imaginary line between the outer canthus of the eye and the most prominent part of the occiput. The superior attachment of the auricle should be above this line (Fig 4).

Pitfalls: Subjective impression of ear placement seems to be influenced by the position of the person's head relative to that of the observer. In the frontal view, the ears are subjected to parallax. If the neck is extended, they appear low. If it is flexed, they seem high. In the lateral view, ear position seems to be judged in relation to the vertex above, and the chin and level of the tip of the shoulder below. A high ratio between these distances gives the impression of low-set ears (Gripp et al., 2013).

\section{Statistics}

Statistical analysis and presentation of data was conducted using IBM SPSS statistics version 21 (Armonk, NY). Data were presented as mean and standard deviation. One- way ANOVA was used to compare the mean length, width and position in the different age groups. Unpaired Student t-test was used to evaluate the difference among both sexes. Paired t-test was used to evaluate the symmetry of both Rt and Lt ears. In addition, linear correlation coefficient, simple linear regression, and ROC curve were used to assess the accuracy of age and sex prediction respectively. Results were considered significant when $\mathrm{P}$ value $\leq 0.05$ (Dawson-Saunders and Trapp, 2001).

\section{Results}

In this study, the recruited sample showed nearly equal sex distribution where males represented $50.23 \%$, while females represented $49.77 \%$. Regarding the distribution of the study participants in the different age groups, table (1) shows that the highest percentage was in the age group from 18 years to less than 40 years $(29.11 \%)$ while the lowest percentage $(7.04 \%)$ was in the age group from 4 years to less than 5 years.

Table (2) illustrates no significant differences in the mean auricular length and width between Rt and Lt ears. Only the position of the auricles showed no symmetry with significant difference $(p<0.001)$ in mean positions of ear auricles between Rt and Lt ears.

Table (3) shows a statistically significant difference between the mean length of ear auricles of both Rt and Lt ears in the different age groups ( $p<0.001$ and 0.008) respectively. Additionally, no significant difference was observed in the mean length of ear auricles between Rt and Lt ears in each age group.

As regards width of ear auricle, there was a statistical significant difference between mean width of Rt and Lt ears in the different age groups with no significant difference observed between Rt and Lt ears in each age group (Table 4). 
Comparison of the mean position of ear auricles in both Rt and Lt ears in different age groups revealed a statistical significant difference $(\mathrm{p}<0.001)$. Additionally, there was no significant difference in mean position of ear auricles between Rt and Lt sides in each age group except in the growing age group (between 7 years and less than 18 years) and in ages $\geq 40$ years (Table 5 ).

The current study revealed a statistical significant linear positive correlation between each of auricular length, width and position in both Rt and Lt ears and age of the studied subjects $(p<0.001)$ as shown in table (6).

Table (7) shows that the length of the Rt auricle was significantly predictable of age $(p<0.001)$ and it contributed to $42.59 \%$ of variation in age (Coefficient of variation $\mathrm{R}^{2}=42.597 \%$ ). The regression equation also shows that for every unit increase in Rt auricular length $(1 \mathrm{~cm})$, the age increases by 19.921years.

Age (years) $=-91.884+(19.921 \times$ right auricular length).

As regards the effects of sex on ear auricle measurements, table (8) shows statistical significant differences in the mean lengths, widths and positions of ear auricle between both sexes; they were significantly higher in females than in males in both ears. It also shows a statistical significant difference between mean right and left ear positions in both sexes $(\mathrm{p}=0.05$ and 0.003 ) respectively.

For assessment of the validity of the studied ear measurements in predicting sex ROC curves were constructed. The results from ROC curve analysis demonstrated that Rt auricle length of $6.30 \mathrm{~cm}$ or lower was predictive of female sex with $64.62 \%$ sensitivity. At a similar cut off length of $\leq 6.30 \mathrm{~cm}$, a left auricle length was predictive of female sex with $69.34 \%$ sensitivity. At a cut off of $\leq 3.30 \mathrm{~cm}$, Rt auricle width was predictive of female sex with $71.70 \%$ sensitivity while a left auricle width of $\leq 3.20 \mathrm{~cm}$ was predictive of female sex with $62.74 \%$ sensitivity. The right auricle position of $\leq 1.70$ $\mathrm{cm}$ was predictive of female sex with $85.85 \%$ sensitivity. At a cut off position of $\leq 1.50 \mathrm{~cm}$, the left auricle position can predict female sex with $74.53 \%$ sensitivity as shown in figs (5-10). Table (9) shows that all the studied measurements were valid in discriminating males from females (ROC area greater than 0.6) with Rt and Lt ear positions were the most sensitive parameters $(85.85 \%$ and $74.53 \%)$ respectively. However, the Lt width showed the best accuracy (72.4\%) of sex prediction.

Table (1): Distribution of the studied subjects in different age groups

\begin{tabular}{|c|c|c|}
\hline Age groups ( years) & No. & $\mathbf{\%}$ \\
\hline $\mathbf{4 -}<\mathbf{5}$ & 30 & 7.04 \\
\hline $\mathbf{5}-<\mathbf{7}$ & 31 & 7.2 \\
\hline $\mathbf{7 -}<\mathbf{1 8}$ & 62 & 14.55 \\
\hline $\mathbf{1 8}-<\mathbf{4 0}$ & 124 & 29.10 \\
\hline $\mathbf{4 0}-<\mathbf{6 0}$ & 121 & 28.40 \\
\hline $\mathbf{2 6 0}$ & 58 & 13.61 \\
\hline Total & 426 & 100.00 \\
\hline
\end{tabular}

Table (2): Paired t- test for statistical analysis of differences between right and left auricles of the studied subjects regarding length, width and position

\begin{tabular}{|c|c|c|c|c|c|}
\hline \multicolumn{2}{|c|}{ Parameters } & \multirow[t]{2}{*}{ Range (cm) } & \multirow[t]{2}{*}{ Mean \pm SD (cm) } & \multicolumn{2}{|c|}{ Paired t-test } \\
\hline & & & & t & P-value \\
\hline \multirow[t]{2}{*}{ Length } & Rt ear & $4.40-8.70$ & $6.288 \pm 0.679$ & \multirow[t]{2}{*}{1.180} & \multirow[t]{2}{*}{0.239} \\
\hline & Lt ear & $4.00-8.50$ & $6.271 \pm 0.705$ & & \\
\hline \multirow[t]{2}{*}{ Width } & Rt ear & $2.00-4.50$ & $3.296 \pm 0.374$ & \multirow[t]{2}{*}{-0.899} & \multirow[t]{2}{*}{0.369} \\
\hline & Lt ear & $2.40-4.50$ & $3.306 \pm 0.351$ & & \\
\hline \multirow[t]{2}{*}{ Position } & Rt ear & $0.20-4.70$ & $1.527 \pm 0.423$ & \multirow[t]{2}{*}{3.513} & \multirow[t]{2}{*}{$<0.001^{*}$} \\
\hline & Lt ear & $0.30-2.50$ & $1.477 \pm 0.331$ & & \\
\hline
\end{tabular}

*; significant at $p \leq 0.05$ 
Table (3): ANOVA followed by Tukey's test (post hoc test) for comparison of the mean length of both right and left auricles in the different studied age groups, Paired t-test for statistical analysis of differences between right and left mean length of ear auricles in each age group

\begin{tabular}{|c|c|c|c|c|c|}
\hline \multirow{2}{*}{\multicolumn{2}{|c|}{$\begin{array}{l}\text { Age groups } \\
\text { (years) }\end{array}$}} & $\begin{array}{l}\text { Rt ear length } \\
\text { (cm) }\end{array}$ & $\begin{array}{l}\text { Lt ear length } \\
(\mathrm{cm})\end{array}$ & \multicolumn{2}{|c|}{ Paired t-test } \\
\hline & & Mean \pm SD & Mean \pm SD & $t$ & P-value \\
\hline \multicolumn{2}{|c|}{$4-<5$} & $5.267 \pm 0.369$ & $5.180 \pm 0.511$ & 1.680 & 0.104 \\
\hline \multicolumn{2}{|c|}{$5-<7$} & $5.510 \pm 0.487$ & $5.503 \pm 0.481$ & 0.134 & 0.894 \\
\hline \multicolumn{2}{|c|}{$7-<18$} & $5.960 \pm 0.501$ & $5.919 \pm 0.506$ & 1.284 & 0.204 \\
\hline \multicolumn{2}{|c|}{$18-<40$} & $6.290 \pm 0.478$ & $6.315 \pm 0.503$ & -0.838 & 0.404 \\
\hline \multicolumn{2}{|c|}{$40-<60$} & $6.650 \pm 0.539$ & $6.611 \pm 0.556$ & 1.478 & 0.142 \\
\hline \multicolumn{2}{|c|}{$\geq 60$} & $6.824 \pm 0.557$ & $6.821 \pm 0.589$ & 0.083 & 0.934 \\
\hline \multirow[t]{2}{*}{ ANOVA } & $F$ & 20.078 & 3.196 & & \\
\hline & P-value & $<0.001^{*}$ & $0.008^{*}$ & & \\
\hline \multicolumn{2}{|c|}{ Tukey's test } & $\begin{array}{l}\text { There are } \\
\text { significant } \\
\text { differences } \\
\text { between all } \\
\text { groups except } \\
40-<60 \text { versus } \\
\geq 60 \text { groups. }\end{array}$ & $\begin{array}{l}\text { There are } \\
\text { significant } \\
\text { differences } \\
\text { between all } \\
\text { groups except } \\
40-<60 \text { versus } \geq \\
60 \text { groups. }\end{array}$ & & \\
\hline
\end{tabular}

*; significant at $p \leq 0.05$

Table (4): ANOVA followed by Tukey's test (post hoc test) for comparison of the mean width of both right and left auricles in the different studied age groups, Paired t-test for statistical analysis of differences between Rt and Lt mean width of ear auricles in each age group

\begin{tabular}{|c|c|c|c|c|c|}
\hline \multicolumn{2}{|c|}{$\begin{array}{l}\text { Age groups } \\
\text { (years) }\end{array}$} & \multirow{2}{*}{$\begin{array}{l}\begin{array}{l}\text { Rt ear width } \\
\text { (cm) }\end{array} \\
\text { Mean } \pm \text { SD }\end{array}$} & \multirow{2}{*}{$\begin{array}{l}\begin{array}{c}\text { Lt ear width } \\
\text { (cm) }\end{array} \\
\text { Mean } \pm \text { SD } \\
\end{array}$} & \multicolumn{2}{|c|}{ Paired t-test } \\
\hline & & & & t & P-value \\
\hline \multicolumn{2}{|c|}{$4-<5$} & $3.023 \pm 0.387$ & $3.053 \pm 0.325$ & -0.534 & 0.597 \\
\hline \multicolumn{2}{|c|}{$5-<7$} & $3.071 \pm 0.336$ & $3.116 \pm 0.276$ & -1.141 & 0.263 \\
\hline \multicolumn{2}{|c|}{$7-<18$} & $3.160 \pm 0.334$ & $3.182 \pm 0.273$ & -0.826 & 0.412 \\
\hline \multicolumn{2}{|c|}{$18-<40$} & $3.271 \pm 0.324$ & $3.295 \pm 0.311$ & -1.157 & 0.249 \\
\hline \multicolumn{2}{|c|}{$40-<60$} & $3.360 \pm 0.332$ & $3.367 \pm 0.363$ & -0.313 & 0.755 \\
\hline \multicolumn{2}{|c|}{$\geq 60$} & $3.621 \pm 0.354$ & $3.569 \pm 0.337$ & 1.509 & 0.137 \\
\hline \multirow[t]{2}{*}{$\overline{A N O V A}$} & $F$ & 20.455 & 16.132 & & \\
\hline & P-value & $<0.001 *$ & $<0.001^{*}$ & & \\
\hline \multicolumn{2}{|c|}{ Tukey's test } & $\begin{array}{l}\text { There are } \\
\text { significant } \\
\text { differences } \\
\text { between all } \\
\text { groups except: } \\
7-<18 \text { versus } \\
18-<40 \text {. }\end{array}$ & $\begin{array}{l}\text { There are } \\
\text { significant } \\
\text { differences } \\
\text { between all } \\
\text { groups except: } \\
7<18 \text { versus 18- } \\
<40 \text {. }\end{array}$ & & \\
\hline
\end{tabular}

*; significant at $p \leq 0.05$ 
Table (5): ANOVA followed by Tukey's test (post hoc test) for comparison of the mean position of both right and left auricles in the studied age groups, Paired t-test for statistical analysis of differences between right and left mean position of ear auricles in each age group

\begin{tabular}{|c|c|c|c|c|c|}
\hline \multirow{2}{*}{\multicolumn{2}{|c|}{$\begin{array}{l}\text { Age groups } \\
\text { ( years) }\end{array}$}} & $\begin{array}{l}\text { Rt ear position } \\
\text { (cm) }\end{array}$ & $\begin{array}{l}\text { Lt ear position } \\
\text { (cm) }\end{array}$ & \multicolumn{2}{|c|}{ Paired t-test } \\
\hline & & Mean \pm SD & Mean \pm SD & $\mathbf{t}$ & P-value \\
\hline \multicolumn{2}{|c|}{$4-<5$} & $1.427 \pm 0.643$ & $1.243 \pm 0.305$ & 1.821 & 0.079 \\
\hline \multicolumn{2}{|c|}{$5-<7$} & $1.287 \pm 0.317$ & $1.268 \pm 0.288$ & 0.649 & 0.522 \\
\hline \multicolumn{2}{|c|}{$7-<18$} & $1.542 \pm 0.336$ & $1.476 \pm 0.271$ & 2.310 & $0.024^{*}$ \\
\hline \multicolumn{2}{|c|}{$18-<40$} & $1.437 \pm 0.341$ & $1.455 \pm 0.321$ & -0.964 & 0.337 \\
\hline \multicolumn{2}{|c|}{$40-<60$} & $1.652 \pm 0.476$ & $1.571 \pm 0.347$ & 2.488 & $0.014 *$ \\
\hline \multicolumn{2}{|c|}{$\geq 60$} & $1.621 \pm 0.355$ & $1.559 \pm 0.304$ & 2.277 & $0.027 *$ \\
\hline \multirow[t]{2}{*}{ ANOVA } & $F$ & 6.546 & 9.029 & & \\
\hline & P-value & $<0.001^{*}$ & $<0.001^{*}$ & & \\
\hline \multicolumn{2}{|c|}{ Tukey's test } & $\begin{array}{lr}\text { There } & \text { are } \\
\text { significant } & \\
\text { differences } & \\
\text { between } & \text { all } \\
\text { groups } 40-<60 \\
\text { versus } \geq 60 \\
\text { groups. }\end{array}$ & $\begin{array}{lr}\text { There } & \text { are } \\
\text { significant } & \\
\text { differences } & \\
\text { between } & \text { all } \\
\text { groups } 40-<60 \\
\text { versus } \geq & 60 \\
\text { groups. } & \end{array}$ & & \\
\hline
\end{tabular}

*; significant at $p \leq 0.05$

Table (6): Pearson's correlation coefficients between the analyzed measurements (length, width and position) and age of the studied subjects

\begin{tabular}{|c|c|c|}
\hline \multirow{2}{*}{ Parameters (cm) } & \multicolumn{2}{|c|}{ Age (years) } \\
\cline { 2 - 3 } & r coefficient & P-value \\
\hline Rt length & 0.654 & $<0.001^{*}$ \\
\hline Lt length & 0.627 & $<0.001^{*}$ \\
\hline Rt Width & 0.438 & $<0.001^{*}$ \\
\hline Lt Width & 0.393 & $<0.001^{*}$ \\
\hline Rt position & 0.194 & $<0.001^{*}$ \\
\hline Lt position & 0.251 & $<0.001^{*}$ \\
\hline
\end{tabular}

*; significant at $p \leq 0.05$

Table (7): Simple linear regression between age of the studied subjects and right auricle length

\begin{tabular}{|c|c|c|c|c|c|c|}
\hline \multirow{2}{*}{ Regression } & \multicolumn{2}{|c|}{} & & \multicolumn{2}{|c|}{ Unpaired t- test } & \multirow{2}{*}{$\mathbf{R}^{2}$} \\
\cline { 2 - 6 } & $\mathbf{B}$ & Standard Error & Beta & $\mathbf{t}$ & P-value & \\
\hline (Constant) & -91.884 & 7.083 & & -12.972 & $<0.001^{*}$ & $42.597 \%$ \\
\hline Rt Length & 19.921 & 1.120 & 0.654 & 17.787 & $<0.001^{*}$ & \\
\hline
\end{tabular}

*; significant at $p \leq 0.05$ 
Table (8): Unpaired t- test for comparison of mean length, width and position of right and left auricles between both sexes. Paired t-test to analyze differences between right and left mean length, width and position of ear auricles in both genders

\begin{tabular}{|c|c|c|c|c|c|c|}
\hline & \multirow{2}{*}{$\begin{array}{c}\text { Rt ear } \\
\text { Mean } \pm \text { SD }\end{array}$} & \multirow{2}{*}{$\begin{array}{c}\text { Lt ear } \\
\text { Mean } \pm \text { SD }\end{array}$} & \multicolumn{2}{|c|}{ Paired t-test } \\
\hline & & & & & $\mathbf{t}$ & P-value \\
\hline \multirow[t]{4}{*}{ Length (cm) } & \multicolumn{2}{|c|}{ Female } & $6.470 \pm 0.694$ & $6.472 \pm 0.722$ & -0.094 & 0.925 \\
\hline & \multicolumn{2}{|l|}{ Male } & $6.104 \pm 0.613$ & $6.068 \pm 0.627$ & 1.736 & 0.084 \\
\hline & \multirow[t]{2}{*}{ Unpaired t- test } & $t$ & 5.763 & 6.156 & & \\
\hline & & P-value & $<0.001^{*}$ & $<0.001^{*}$ & & \\
\hline \multirow[t]{4}{*}{ Width (cm) } & \multicolumn{2}{|c|}{ Female } & $3.409 \pm 0.350$ & $3.443 \pm 0.325$ & -2.019 & 0.045 \\
\hline & \multicolumn{2}{|l|}{ Male } & $3.181 \pm 0.363$ & $3.168 \pm 0.323$ & 0.713 & 0.477 \\
\hline & \multirow[t]{2}{*}{ Unpaired t- test } & $t$ & 6.623 & 8.751 & & \\
\hline & & P-value & $<0.001^{*}$ & $<0.001^{*}$ & & \\
\hline \multirow[t]{4}{*}{ Position (cm) } & \multicolumn{2}{|l|}{ Female } & $1.574 \pm 0.448$ & $1.536 \pm 0.370$ & 1.943 & $0.05^{*}$ \\
\hline & \multicolumn{2}{|l|}{ Male } & $1.479 \pm 0.392$ & $1.417 \pm 0.274$ & 3.014 & $0.003 *$ \\
\hline & \multirow[t]{2}{*}{ Unpaired t- test } & $t$ & 2.341 & 3.754 & & \\
\hline & & P-value & $0.02 *$ & $<0.001^{*}$ & & \\
\hline
\end{tabular}

*; significant at $p \leq 0.05$

Table (9): ROC curve analysis of the studied measurements in predicting sex; showing the best cut-off values, sensitivity, specificity and area under the curves

\begin{tabular}{|l|l|l|l|l|l|l|}
\hline & $\begin{array}{c}\text { Cut-off } \\
\text { value }\end{array}$ & $\begin{array}{c}\text { Sensitivity } \\
\text { \% }\end{array}$ & $\begin{array}{c}\text { Specificity } \\
\text { \% }\end{array}$ & $\begin{array}{c}\text { Accuracy } \\
\%\end{array}$ & ROC- AUC & P value \\
\hline Rt Length & $\leq 6.3$ & 64.62 & 59.81 & 65.8 & 0.658 & $<0.0001^{*}$ \\
\hline Lt Length & $\leq 6.3$ & 69.34 & 59.81 & 67 & 0.670 & $<0.0001^{*}$ \\
\hline Rt width & $\leq 3.3$ & 71.70 & 56.07 & 68.3 & 0.683 & $<0.0001^{*}$ \\
\hline Lt width & $\leq 3.2$ & 62.74 & 70.09 & 72.4 & 0.724 & $<0.0001^{*}$ \\
\hline Rt position & $\leq 1.7$ & 85.85 & 32.24 & $58 \%$ & 0.580 & $<0.0039^{*}$ \\
\hline Lt position & $\leq 1.5$ & 74.53 & 49.53 & $61.4 \%$ & 0.614 & $<0.0001^{*}$ \\
\hline
\end{tabular}

AUC; area under the curve, *; significant at $p \leq 0.05$

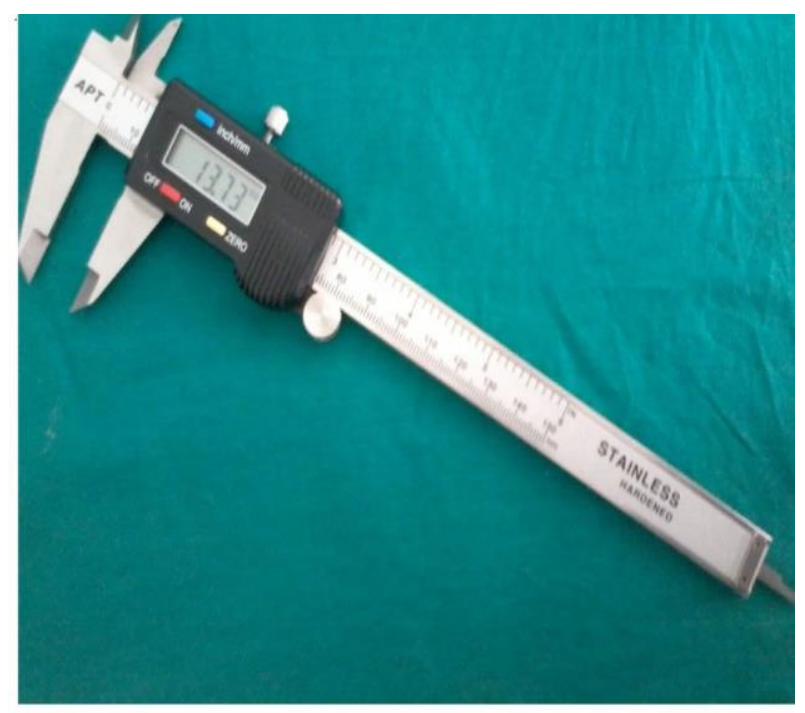

Fig (1): Electronic digital caliper

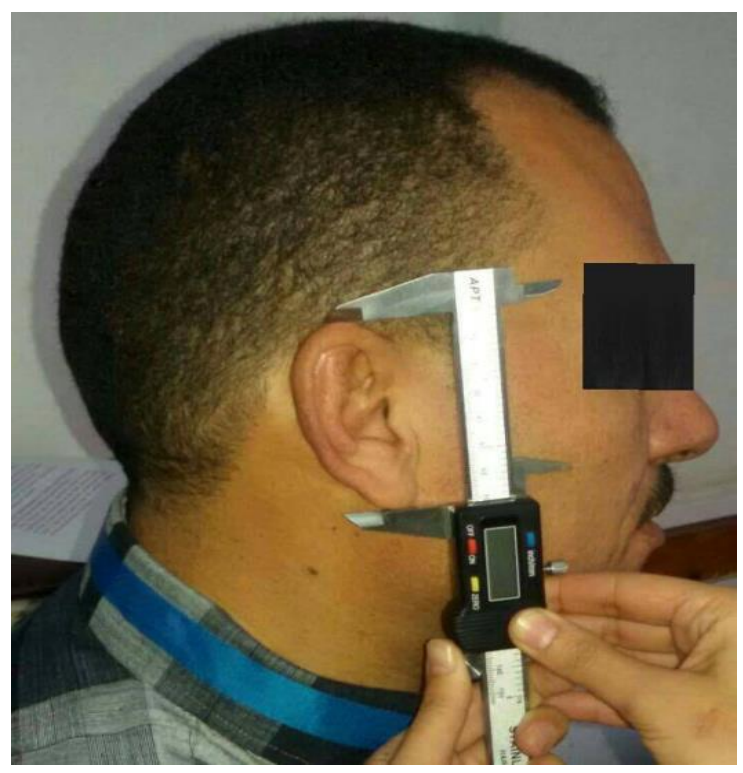

Fig (2): Measurement of ear length according to Gripp et al. (2013) 


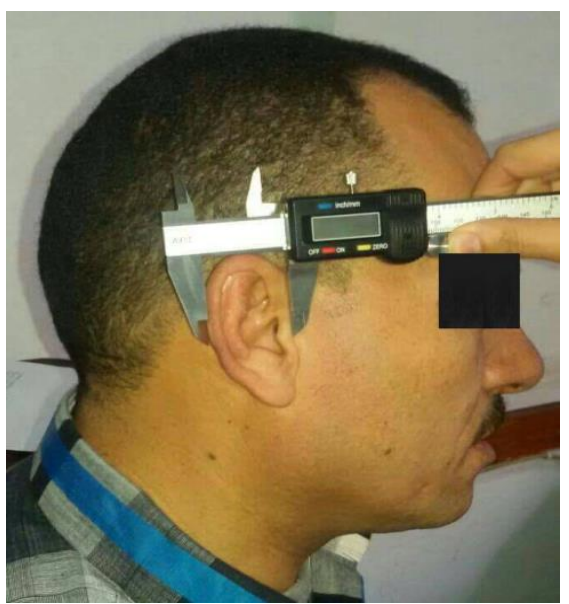

Fig (3): Measurement of ear width according to Gripp et al. (2013)

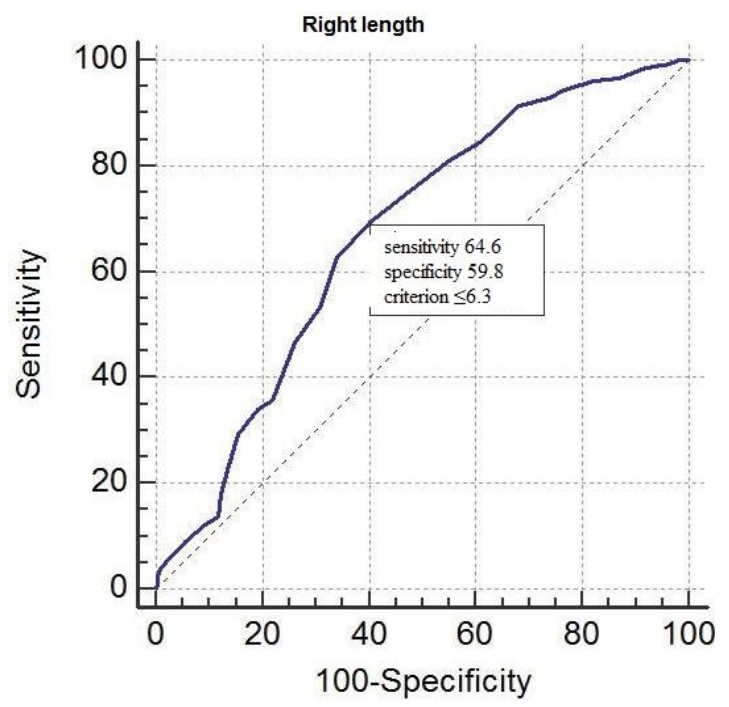

Fig (5): ROC curve, the best cut-off value, sensitivity and specificity of right length for prediction of sex

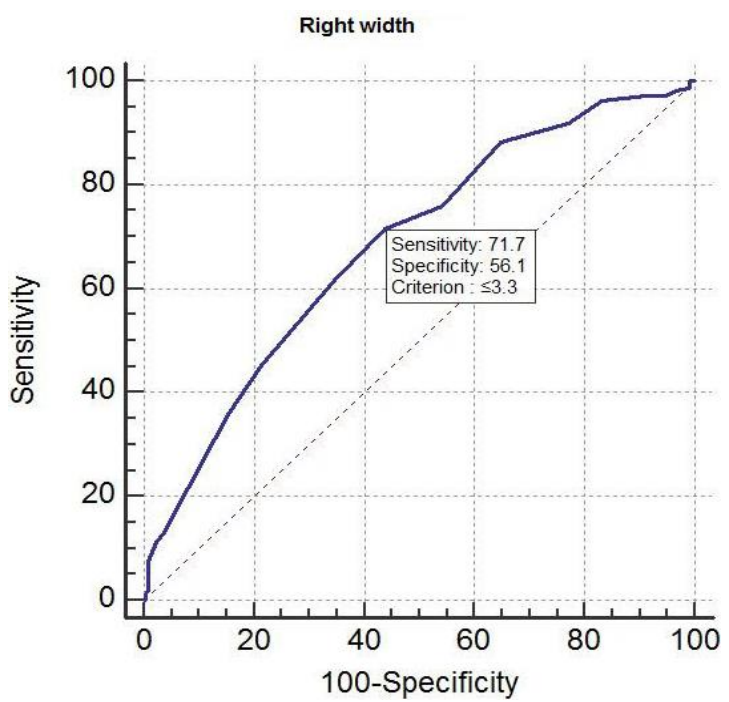

Fig (7): ROC curve, the best cut-off value, sensitivity and specificity of right width for prediction of sex

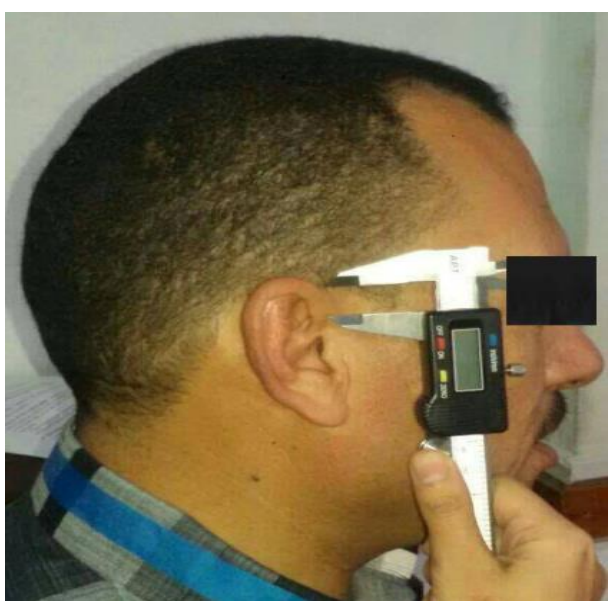

Fig (4): Measurement of ear position according to Gripp et al. (2013)

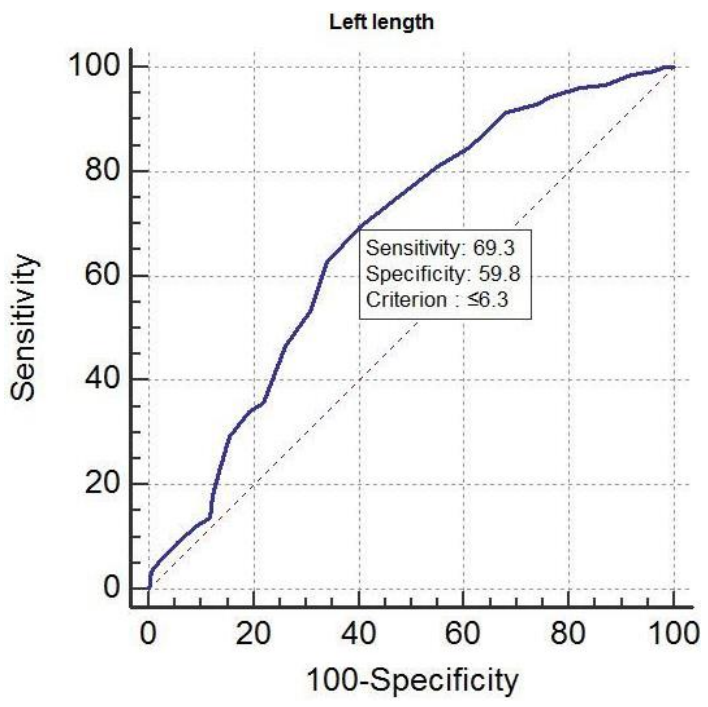

Fig (6): ROC curve, the best cut-off value, sensitivity and specificity of left length for prediction of sex

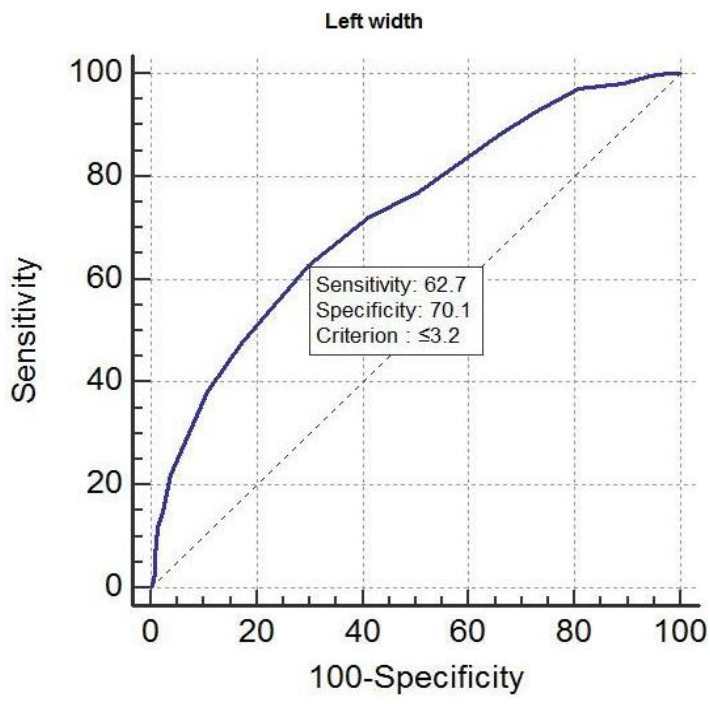

Fig (8): ROC curve, the best cut-off value, sensitivity and specificity of left width for prediction of sex 


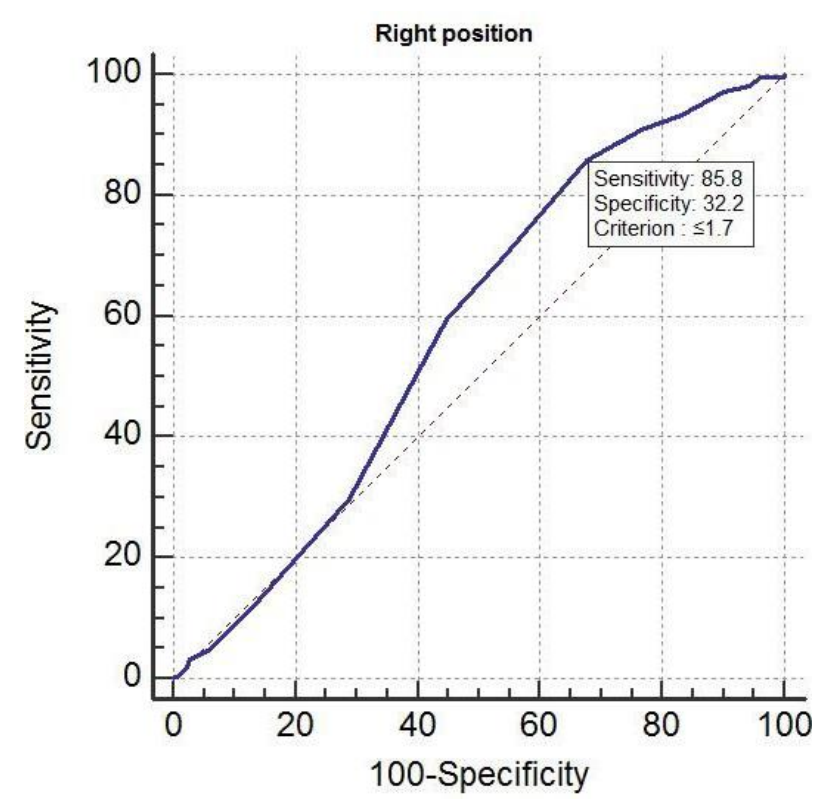

Fig (9): ROC curve, the best cut-off value, sensitivity and specificity of right position for prediction of sex

\section{Discussion}

Biometrics identification methods proved to be very efficient, more natural and easy for forensic investigators than traditional methods of human identification. Ear biometrics has large volume of unique features that allow us to identify humans (Rahman et al., 2007). This is based on the fact that human ears are among those body structures that continue to grow along entire life time, well beyond the end of their organogenesis (Hunter and Yotsuyanagi, 2005).

In the last twenty years, normal sex-related dimensions of ears in addition to growth changes between childhood and old age have been investigated in different ethnic groups using both three-dimensional anthropometry and photography (Ferrario et al., 2001; Ito et al., 2001; Meijerman et al., 2007; Niemitz et al., 2007 ; Sharma et al., 2007). To the best of our knowledge, the current study is the first one investigated the auricular biometrics as potential tools for age and sex identification in Egyptian population sample.

This study showed symmetry between Rt and Lt ears as regards length and width in both sexes and in the different studied age groups. This finding is similar to that obtained by Ferrario et al. (2001); Azaria et al. (2003) and Sforza et al. (2013) who found bilateral ear symmetry in all measurements in adult Indian, Jews and Turkish populations respectively. On the other hand, significant asymmetric ear position in between Rt and Lt ears between both sexes and in the growing age group (7 to less than 18) and in age groups older than 40 years was detected. This finding disagrees with Lian et al. (2008) who found $5 \%$ difference in the vertical ear position between both ears since birth in Singapore newborns.

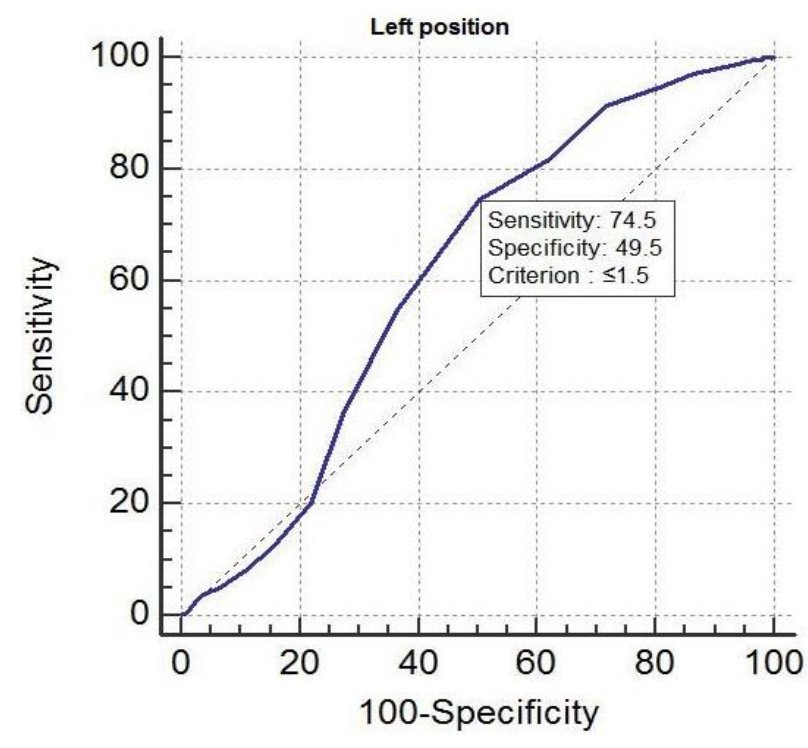

Fig (10): ROC curve, the best cut-off value, sensitivity and specificity of left position for prediction of sex

Differences in ear positions relative to midline facial landmark were also detected by Coward et al. (2000).

The present study revealed a statistical significant difference between mean length and width of Rt and Lt ear auricles in different age groups. They increased progressively with age (a statistically significant linear positive correlation). This finding may be attributed to progressive modifications of the microscopic structure of ear cartilage with aging with reductions in elastic fibers and in the density of cartilage cells (Ito et al., 2001). Overall, the observed microscopic modifications may explain the macroscopic increments in ear dimensions. Age-related reductions of skin elasticity and resilience with the diminutive tensile strength of the connective tissue, and gravitational forces as stated by Purkait and Singh (2007) could also explain this result. This finding is supported by relevant studies in other ethnic groups (Ferrario et al., 2001; Ito et al., 2001; Meijerman et al., 2007; Niemitz et al., 2007 ; Sharma et al., 2007).

The adult increments in auricular dimensions cannot be explained by natural selection: it is not true that persons with bigger ears live longer (Meijerman et al., 2007). Instead of this, Gualdi-Russo, (1998) performed a longitudinal anthropometric study with a 10-year follow up period; at the second examination, persons were aged 31 to more than 60 years, significant age-related increments in ear length were found with smaller nonsignificant variations in ear width. Furthermore, Azaria et al. (2003) suggested that $85 \%$ of the growth of the ear occurs before 3 years old and the remaining $15 \%$ occurs before age of twenty. After this age, further minor 
increases are attributable mainly to elongation of the ear lobe secondary to gravitational forces.

Simple linear regression showed that the length of the right auricle was significant predictable of age where, it can provide us with $42.597 \%$ of information needed to predict age. Moreover, the regression equation revealed that for every unit increase in auricle length (1 $\mathrm{cm})$, the age increase by 19.921. Compared to this finding, Azaria et al. (2003) prepared regression models for Jewish in order to predict age in men and women depending on ear lobe length. They reported that ear lobe length was significantly predictable for age with accuracy (coefficient of variation R2) was 35\% and 34\% for the Lt and Rt ear lobes respectively. This emphasizes that auricular length increases with age in both sexes.

In the current study, both auricular length and width showed statistically significant differences between both sexes where, the Egyptian females had longer and wider auricles than in males at all age groups beginning from the fourth year. These increments in length may be attributed to earring wearing habit which is considered as an additional weight on the ears, and they therefore affect auricular height (Azaria et al., 2003). In contrast, in other ethnic groups (Ito et al. (2001); Bozkir et al. (2006) and Agnihotri and Singh (2007) reported that males have larger auricular length than females.

Kalcioglu et al. (2006) and Lian et al. (2008) stated that, sexual dimorphism in ear dimensions appears to begin with post natal growth; at birth, and within the first 24 months of life. Similar dimensions in newborns and children boys and girls were found. In contrast, Agnihotri and Singh (2007) reported significant larger auricles in Indian boys than in girls at birth and in the first months of life.

As a result of sex and age interaction, differences were found in the patterns of increment of both auricular length and width between sexes. In the present investigation, the post-maturity growth of ear dimensions continued in both sexes without apparent stops. Similar findings were reported for adult Dutch and German Caucasians (Meijerman et al., 2007 and Niemitz et al., 2007). In Japanese subjects, Ito et al. ( 2001) found that between birth and 99 years of age, the increment was continuous in women, but it stopped around 50 (ear width) and 70 (ear length) years of age in men. The same finding was reported by Meijerman et al. (2007) who stated that auricle expansion has a slower start in women than in men, but it continues to an older age.

ROC curve analysis revealed that all the studied measurements were significantly valid in discriminating males from females (ROC area greater than 0.6) with Rt and Lt ear positions were the most sensitive parameters ( $85.85 \%$ and $74.53 \%$ ) respectively but, the Lt width showed the best accuracy (72.4\%). Chan and Kumar (2012) and Kumar and Wu (2012) reported higher accuracy, sensitivity and specificity when studied sex prediction from ear biometrics using two dimensional methods. Furthermore, Theoharis et al. (2008) and Islam et al. (2013) obtained a verification rate of $84.8 \%$ for sex prediction from ear biometrics using three dimensional methods. The observed conflicting results regarding sensitivity, specificity and accuracy of sex prediction using ear biometrics may be explained by the differences in the used methods of auricular measurements in addition to the racial differences.

\section{Conclusion}

Finally, it could be concluded that a progressive age related increments was found in auricular length, width, and position. In addition, Egyptian females showed larger auricular dimensions compared to males in both ears. Ear length, width, and position could be useful tools of sex determination of Egyptian population. Furthermore, right ear length can help in age estimation as shown in this equation Age (years) $=-91.884+(19.921$ Rt auricle length). Further comparative studies using two dimensional and three dimensional methods of ear measurements are recommended.

\section{References}

Agnihotri G and Singh D (2007): Craniofacial Anthropometry in Newborns and Infants. Iran J Pediatr. 17(4): 332-338.

Azaria R, Adler N, Silfen R et al., (2003): Morphometry of the adult human earlobe: a study of 547 subjects and clinical application. Plast Reconstr Surg. 111(7): 2398-2402.

Bozkir MG, Karakas P, Yavuz M et al., (2006): Morphometry of the external ear in our adult population. Aesthetic Plast Surg. 30(1): 81-85.

Chan TS and Kumar A (2012): Reliable ear identification using 2-D quadrature filters. Pattern Recogn Lett. 33(14): 1870-1881.

Chen $\mathrm{H}$ and Bhanu B (2007): Human ear recognition in 3D. IEEE Trans Pattern Anal Mach Intell. 29(4): 718-737.

Chen L, Mu Z, Zhang B et al., (2015): Ear recognition from one sample per person PLoS One. 10 (5): e0129505.

Coward T J, Scott B J, Watson R M et al., (2000): Laser scanning of the ear identifying the shape and position in subjects with normal facial symmetry. Int J Oral Maxillofac Surg. 29(1): 18-23.

Dawson-Saunders B and Trapp R (2001): Basic and clinical biostatics. 3rd ed. McGrow Hill McGrow Hill Medical Publishing Division.

Ferrario VF, Sforza C, Ciusa V et al., (2001): The effect of sex and age on facial asymmetry in healthy subjects: a cross-sectional study from adolescence to mid-adulthood. J Oral Maxillofac Surg. 59(4): 382-388.

Gripp KW, Anne M and Slavotinek AM (2013): Handbook of Physical Measurements, Oxford Handbook Series (Vol. 3): Oxford.pp.135-145.

Gualdi-Russo E (1998): Longitudinal study of anthropometric changes with aging in an urban Italian population. Homo. 49: 241-259. 
Hunter, AGW and Yotsuyanagi T (2005): The external ear: More attention to detail may aid syndrome diagnosis and contribute answers to embryological questions. Am J Med Genet A. 135A(3): 237-250.

Islam SMS, Davies R, Bennamoun M et al., (2013): Multibiometric human recognition using 3D ear and face features. Pattern Recognition. 46(3):613-627.

Ito I, Imada M, Ikeda M et al., (2001): A morphological study of age changes in adult human auricular cartilage with special emphasis on elastic fibers. Laryngoscope. 111(5): 881-886.

Kalcioglu MT, Toplu Y, Ozturan O et al., (2006): Anthropometric growth study of auricle of healthy preterm and term newborns. Int J Pediatr Otorhinolaryngol. 70(1): 121-127.

Kumar A and Wu C (2012): Automated human identification using ear imaging. Pattern Recogn. 45(3): 956-968.

Lian WB, Cheng MS, Tion IH et al., (2008): Auricular Anthropometry of Newborns at the Singapore General Hospital. Ann Acad Med Singapore. 37: 383-389.

Masaoud K, Algabary S, Omar S et al., (2013): A Review Paper on Ear Recognition Techniques: Models, Algorithms and Methods. Australian Journal of Basic and Applied Sciences. 7(1): 411-421.

Meijerman L, van der Lugt C and Maat G J (2007): Cross-sectional anthropometric study of the external ear. J Forensic Sci. 52(2): 286-293.
Niemitz C, Nibbrig M and ZacherV (2007): Human ears grow throughout the entire life time according to complicated and sexually dimorphic patterns-conclusions from a cross-sectional analysis. Anthropol Anz. 65(4): 391-413.

Purkait R (2015): Application of External Ear in Personal Identification: ASomatoscopic Study in Families. Ann Forensic Res Anal. 2(1): 1015.

Purkait R and Singh P( 2007): Anthropometry of the normal human auricle: A study of adult Indian men. Aesthetic Plast Surg. 31(4): 372-379.

Rahman M, Islam R, Bhuiyan NI et al., (2007): Person Identification Using Ear Biometrics. IJCIM. 15(2): 1-8.

Sforza C, Elamin F, Tommasi DG et al., (2013): Morphometry of the soft tissues of the orbital region in Northern Sudanese persons. Forensic Sci Int. 228(1): 180.e181-180.e111.

Sharma A, Sidhu NK, Sharma MK et al., (2007): Morphometric study of ear lobule in northwest Indian male subjects. Anat Sci Int. 82(2): 98104.

Singh D and Singh S (2014): A Survey on Human Ear Recognition System Based on 2D and 3D Ear Images. Open Journal of ISA. 2014(2): 21-30.

Theoharis T, Passalis G, Toderici G et al., (2008): Unified 3D face and ear recognition using wavelets on geometry images. Pattern Recogn. 41(3):796-804.

\section{استخدام القياسات الحيوية لصوان الأذن فى الاستعراف العربى على العمر والجنس فى عينة من المصريين}

ط. حنان فاروق الفارسى ا و د. فاطمة محمد الجزار و ا.د. منى سيد أحمد الجوهرى و ا.د. منى محمد حشمت

يمثل تحديد العمر والجنس مهمة صعبة للطبيب الشرعي مما أدى الى ظهور بحال القياسات الحيوية و يعد الإستعراف لبواسطة القيات القياسات الحيوية

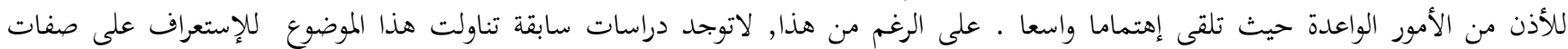

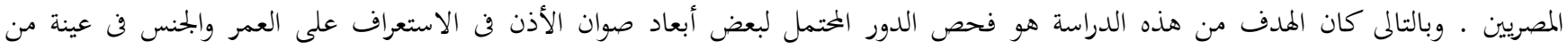

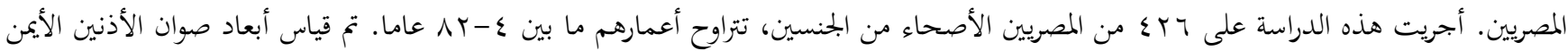

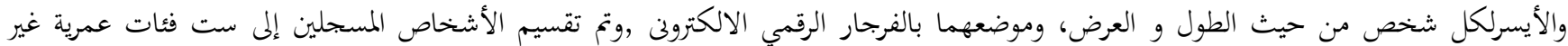

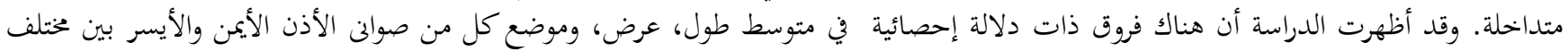

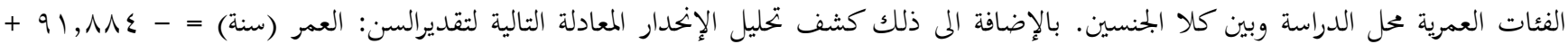

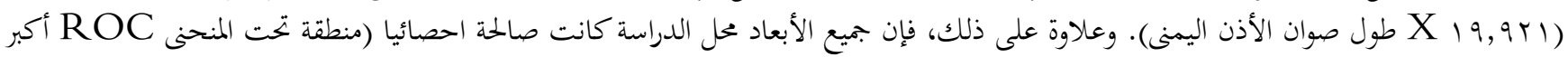

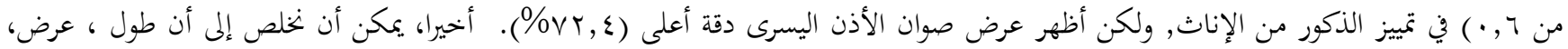

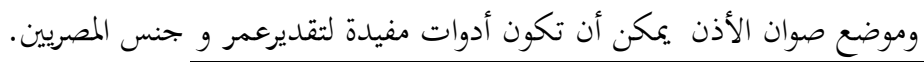
ا الطب الثرعى, قسم المنصورة, وز ارة العدل, مصر.

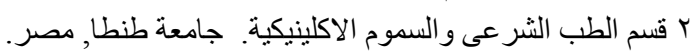

